\title{
Chemical modulation of DNA replication along G-quadruplex based on topology-dependent ligand binding
}

Shuntaro Takahashi, ${ }^{\dagger}$ Anita Kotar ${ }^{\top}$, Hisae Tateishi-Karimata, ${ }^{\dagger}$ Sudipta Bhowmik, ${ }^{\S}$ Zi-Fu Wang, ${ }^{\perp}$ TaChau Chang, ${ }^{\perp}$ Shinobu Sato, ${ }^{\#}$ Shigeori Takenaka, ${ }^{*}$ Janez Plavec ${ }^{\top}$, and Naoki Sugimoto*,t,f

†FIBER (Frontier Institute for Biomolecular Engineering Research), Konan University, 7-1-20 Minatojima-

Minamimachi, Chuo-ku, Kobe 650-0047, Japan

ISlovenian NMR center, National Institute of Chemistry, SI-1000 Ljubljana, Slovenia

§University of Calcutta, University College of Science, 92, A.P.C. Road, Kolkata 700009, India.

$\perp$ Institute of Atomic and Molecular Sciences, Academia Sinica, Taipei 106, Taiwan.

\#Department of Applied Chemistry, Kyushu Institute of Technology, Fukuoka 804-8550, Japan.

ҒFIRST (Graduate School of Frontiers of Innovative Research in Science and Technology), Konan University, 7-1-20 Minatojima-Minamimachi, Chuo-ku, Kobe 650-0047, Japan.

* To whom correspondence should be addressed. Tel: (+81)78-303-1457; Fax: (+81)78-303-1495;

Email: sugimoto@konan-u.ac.jp

\section{CONTENTS}

Table S1. QSTR data were calculated using the parameters listed in Table 2

Table S2. Thermodynamic parameters of G4 formation and replication kinetics of hTel24 without a ligand

Table S3. Thermodynamic parameters of G4 formation and replication kinetics of c-Myc G4 with each ligand

Figure S1. Images of gels shown in Figure 2C stained with SYBR Gold reagent

Figure S2. Time courses of replication products

Figure S3. Effects of various ligands on G4 structure and replication

Figure S4. CD melting curves of $5 \mu \mathrm{M}$ hTel with BMVC-8C3O

Figure S5. Schematic illustration of the QSTR analysis

Figure S6. Binding of cNDI2 to hTel G-quadruplex analyzed by NOESY

Figure S7. The methyl region of the $1 \mathrm{H}$ NMR spectra of hTel

Figure S8. Data in the presence of $1 \mathrm{mM} \mathrm{KCl}$ with or without $20 \mathrm{wt} \%$ PEG200

Figure S9. Effects of cNDI1-py-binding on G4 structure and replication

Figure S10. Effects of ThT on G4 structure and replication

Figure S11. Effects of NDI ligand-binding on c-Myc G4 structure and replication 
Table S1. QSTR data were calculated using the parameters listed in Table 2

\begin{tabular}{|c|c|c|c|c|c|}
\hline Ligand & Condition $^{a}$ & $\begin{array}{l}-\Delta \Delta G^{\circ}{ }_{37} \\
\left(\mathrm{kcal} \mathrm{mol}^{-1}\right)\end{array}$ & $\begin{array}{l}\Delta \Delta G^{\ddagger} 37 \\
\left(\mathrm{kcal} \mathrm{mol}^{-1}\right)\end{array}$ & $S_{i}{ }^{b}$ & $\alpha^{\mathrm{c}}$ \\
\hline NDI-DM & & 1.2 & 0.91 & 0.79 & 1 \\
\hline cNDI1 & 100 mM KCl & 0.51 & 2.1 & 4.1 & 5.2 \\
\hline cNDI2 & \multirow{3}{*}{0 wt $\%$ PEG200 } & 1.1 & 1.6 & 1.5 & 1.9 \\
\hline Fisetin & & -0.39 & -0.062 & 0.16 & 0.20 \\
\hline BMVC-8C $3 \mathrm{O}^{\mathrm{d}}$ & & n.d. & 0.29 & n.d. & n.d. \\
\hline NDI-DM & & 2.4 & 0.84 & 0.34 & 1 \\
\hline cNDI1 & $1 \mathrm{mM} \mathrm{KCl}$ & 2.5 & 2.1 & 0.81 & 2.3 \\
\hline cNDI2 & \multirow{3}{*}{0 wt $\%$ PEG200 } & 1.9 & 1.7 & 0.90 & 2.6 \\
\hline TMPyP4 & & 0.84 & 0.56 & 0.68 & 2.0 \\
\hline BMVC-8C $30^{d}$ & & 3.5 & 2.9 & 0.81 & 2.3 \\
\hline NDI-DM & & 1.1 & 0.64 & 0.59 & 1 \\
\hline cNDI1 & $1 \mathrm{mM} \mathrm{KCl}$ & 2.1 & 1.8 & 0.87 & 1.5 \\
\hline cNDI2 & \multirow{3}{*}{20 wt\% PEG200g } & 0.78 & 1.5 & 1.9 & 3.2 \\
\hline NMM & & -0.1 & 1.7 & -16 & -27 \\
\hline BMVC-8C $3 \mathrm{O}^{\mathrm{d}}$ & & 1.3 & 2.3 & 1.8 & 3.0 \\
\hline
\end{tabular}

a All experiments were performed in $10 \mathrm{mM}$ Tris- $\mathrm{HCl}(\mathrm{pH} 7.5), 1$ or $100 \mathrm{mM} \mathrm{KCl}$, and $8 \mathrm{mM} \mathrm{MgCl}_{2}$ at $37^{\circ} \mathrm{C}$ with or without PEG200.

${ }^{b} S_{i}$ was calculated using the following formula: $\left(\Delta \Delta G^{\ddagger}{ }_{37}\right.$ of each ligand $) /\left(-\Delta \Delta G^{\circ}{ }_{37}\right.$ of each ligand).

${ }^{c} \alpha$ was calculated using the following formula: $S_{i} / S$, where $S$ is the $S_{i}$ of NDI-DM in this study.

${ }^{\mathrm{d}} \mathrm{hTel} 24$ was used.

e Data on TMPyP4 and NMM are not shown because their stabilization had almost no effect.

${ }^{f}$ Data on NMM and fisetin are not shown because their stabilization had almost no effect.

g Data on TMPyP4 and fisetin are not shown because the stability could not be determined or the replication stall had almost no effect, respectively. 
Table S2. Thermodynamic parameters of G4 formation and replication kinetics of hTel24 without a ligand

\begin{tabular}{lcccc} 
Condition & \multicolumn{1}{c}{$T_{\mathrm{m}}\left({ }^{\circ} \mathrm{C}\right)$} & $-\Delta G^{\circ}{ }_{37}\left(\mathrm{kcal} \mathrm{mol}^{-1}\right)$ & $k_{\mathrm{s}}\left(\mathrm{min}^{-1}\right)$ & $k_{\mathrm{f}}\left(\mathrm{min}^{-1}\right)$ \\
\hline $100 \mathrm{mM} \mathrm{KCl}, 0 \mathrm{wt} \%$ PEG200 & $70.2 \pm 0.4$ & $5.1 \pm 0.1$ & $0.36 \pm 0.08$ & $7.6 \pm 1.6$ \\
$1 \mathrm{mM} \mathrm{KCl}, 0 \mathrm{wt} \%$ PEG200 & $42.7 \pm 0.7$ & $0.6 \pm 0.1$ & $4.4 \pm 2.2$ & $71 \pm 40$ \\
$1 \mathrm{mM} \mathrm{KCl}, 20 \mathrm{wt} \%$ PEG200 & $45.4 \pm 0.1$ & $1.1 \pm 0.1$ & $0.49 \pm 0.19$ & $6.3 \pm 1.4$
\end{tabular}


Table S3. Thermodynamic parameters of G4 formation and replication kinetics of c-Myc G4 with each ligand $^{a}$

\begin{tabular}{ccccc} 
Ligand & \multicolumn{1}{c}{$T_{\mathrm{m}}\left({ }^{\circ} \mathrm{C}\right)$} & \multicolumn{1}{c}{$-\Delta \mathrm{G}^{\circ}{ }_{37}\left(\mathrm{kcal} \mathrm{mol}^{-1}\right)$} & \multicolumn{1}{l}{$\mathrm{ks}_{\mathrm{s}}\left(\mathrm{min}^{-1}\right)$} & \multicolumn{1}{c}{$\mathrm{kf}_{\mathrm{f}}\left(\mathrm{min}^{-1}\right)$} \\
\hline None & $58.4 \pm 1.0$ & $3.1 \pm 0.3$ & $(3.1 \pm 0.5) \times 10^{-2}$ & $5.7 \pm 1.6$ \\
NDI-DM & $69.5 \pm 0.6$ & $4.2 \pm 0.3$ & $(2.4 \pm 0.6) \times 10^{-3}$ & $4.8 \pm 1.1$ \\
CNDI1 & $71.6 \pm 2.0$ & $4.6 \pm 0.2$ & $(2.4 \pm 0.5) \times 10^{-3}$ & $3.1 \pm 3.6$ \\
CNDI2 & $68.0 \pm 1.0$ & $5.0 \pm 0.1$ & $(3.4 \pm 0.8) \times 10^{-3}$ & $5.1 \pm 0.9$
\end{tabular}

aThe condition was $1 \mathrm{mM} \mathrm{KCl,} 0$ wt\% PEG200. 

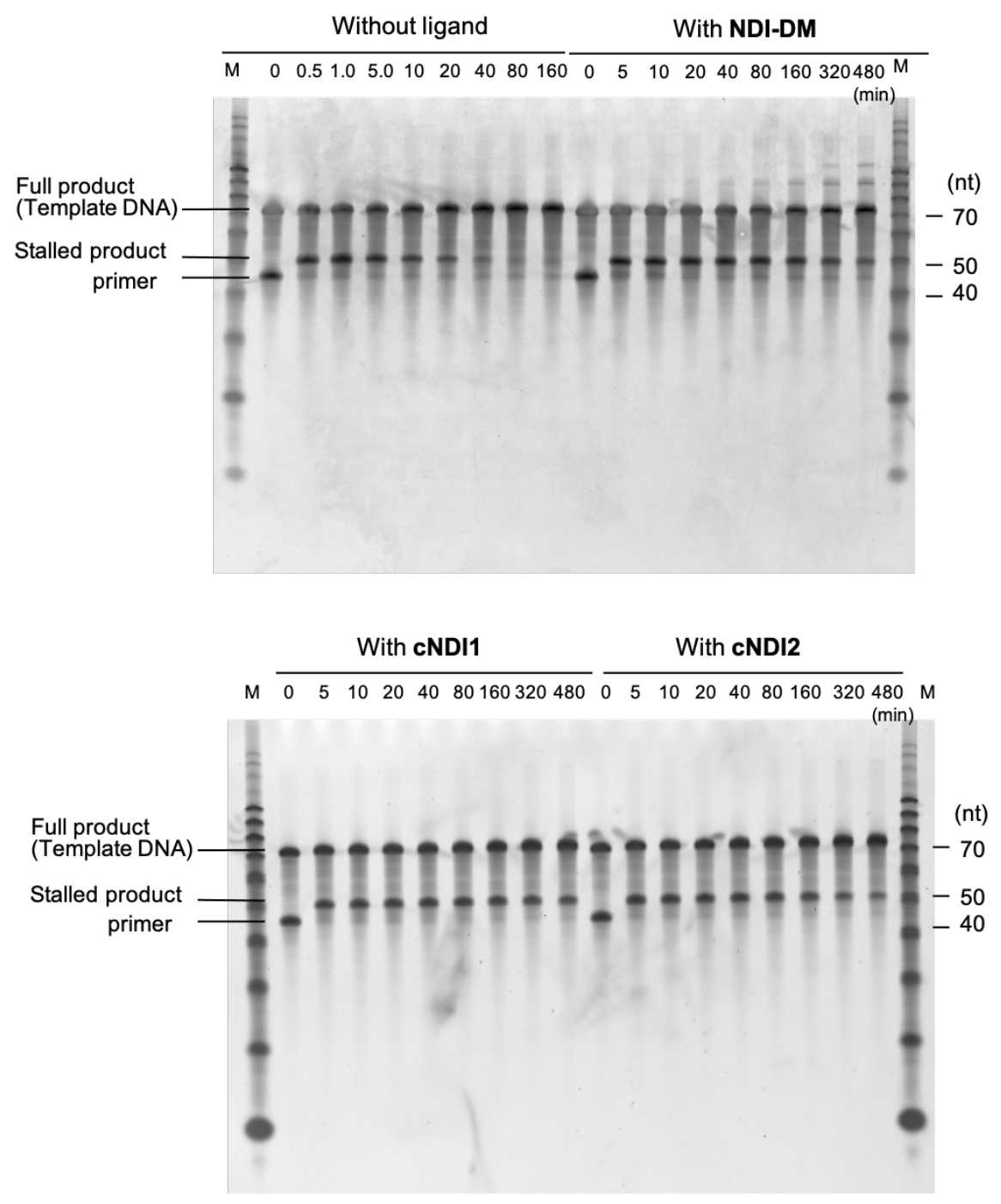

Figure S1. Images of gels shown in Figure 2C stained with SYBR Gold reagent. The fluorescently labeled primer, full-length product, stalled product, and template strand are visible. The molecular weight markers (lanes M) show 10-bp DNA ladder. In each lane, the upper-most band corresponds to the template DNA and the lowest band corresponds to the FAM-labeled primer. The reaction mixture was incubated in the absence or presence of the ligand. In the samples incubated with the enzyme, the full-length product band overlaps with the template DNA, and the stalled product, which migrates just above the primer, is observed. 
(A)

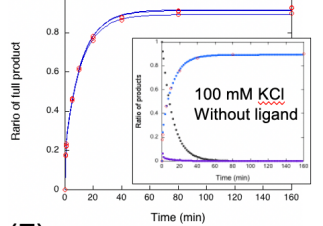

(F)

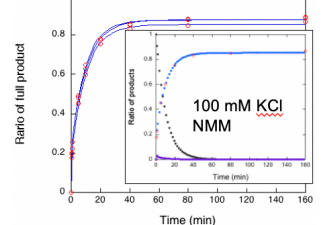

(K) ,

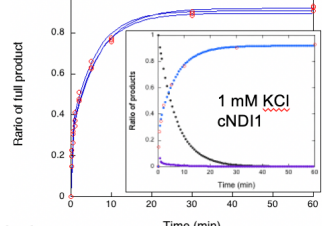

(P)

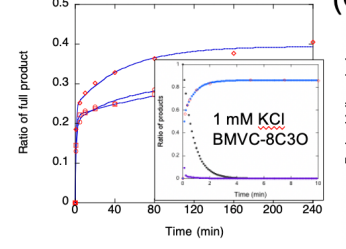

(U)

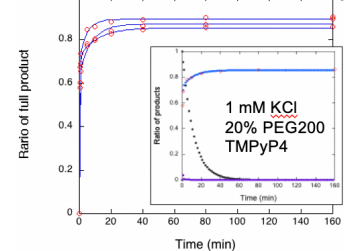

(B)

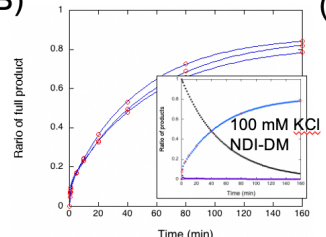

(G)

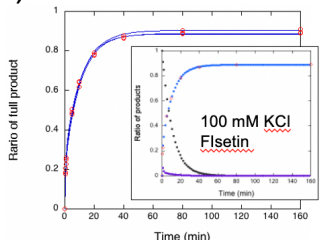

(L)

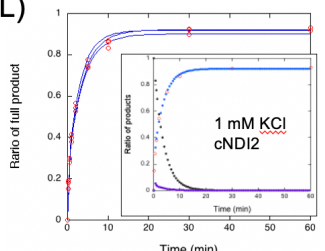

(Q)

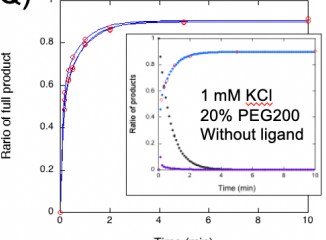

(V)

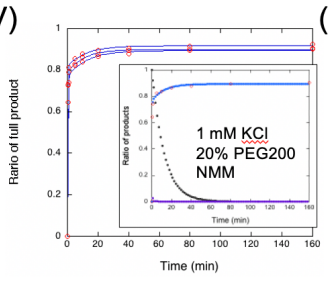

(C)

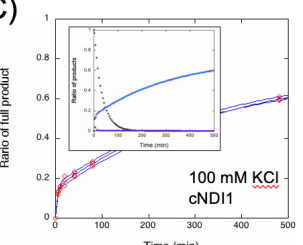

(H)

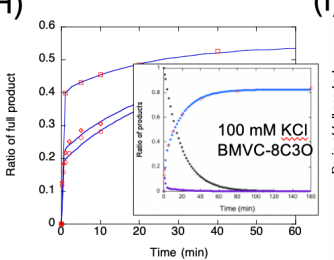

(M)

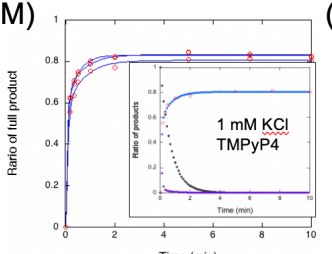

(R)

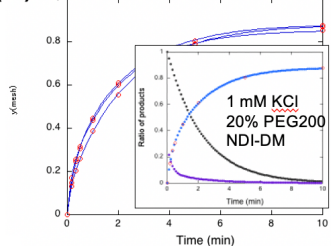

(W)

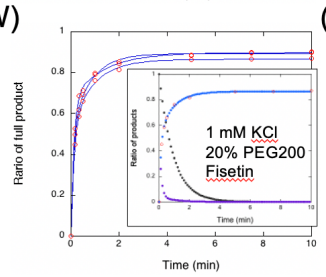

(D)

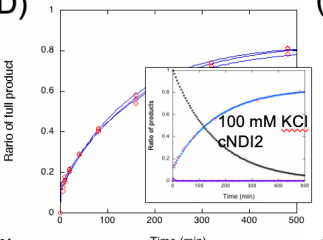

(I)

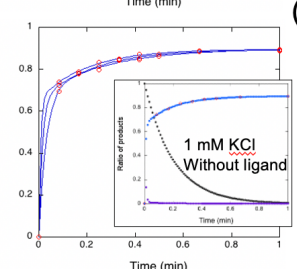

(N)

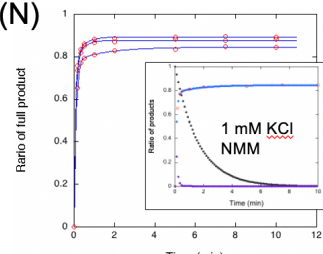

(S)

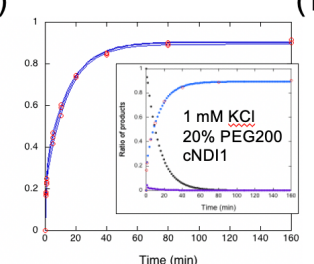

(X)

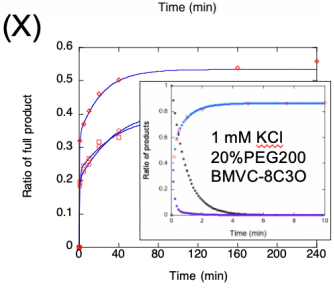

(E)

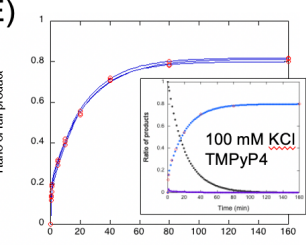

(J)

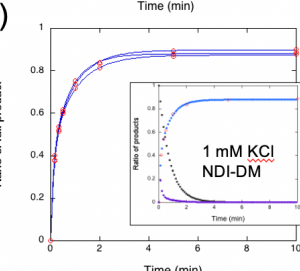

(O)

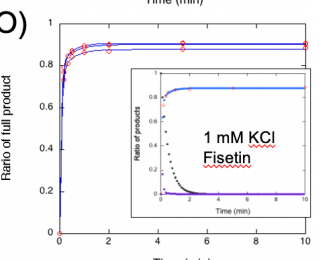

(T)

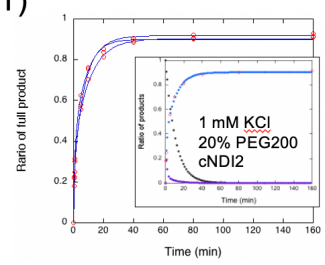

Figure S2. $(\mathrm{A}-\mathrm{H})$ Kinetic analyses of full-length product formation in reactions in $100 \mathrm{mM} \mathrm{KCl}$ without PEG200 and (A) without ligand, (B) with $10 \mu \mathrm{M}$ NDI-DM, (C) with $10 \mu \mathrm{M}$ cNDI1, (D) with $10 \mu \mathrm{M}$ cNDI2, (E) with $10 \mu \mathrm{M}$ TMPyP4, (F) with 10 $\mu \mathrm{M} N M M,(\mathrm{G})$ with $50 \mu \mathrm{M}$ fisetin, and $(\mathrm{H})$ with $10 \mu \mathrm{M}$ BMVC-8C3O. (I-P) Kinetic analyses of full-length product formation in reactions in $1 \mathrm{mM} \mathrm{KCl}$ without PEG200 and (I) without ligand, (J) with $10 \mu \mathrm{M}$ NDI-DM, (K) with $10 \mu \mathrm{M}$ cNDI1, (L) with $10 \mu \mathrm{M}$ cNDI2, (M) with $10 \mu \mathrm{M}$ TMPyP4, (N) with $10 \mu \mathrm{M}$ NMM,,(O) with $50 \mu \mathrm{M}$ fisetin, and (P) with $10 \mu \mathrm{M}$ BMVC-8C3O. (Q-X) Kinetic analyses of full-length product formation in reactions in $1 \mathrm{mM} \mathrm{KCl}$ and 20 wt\% PEG200 and (Q) without ligand, (R) with 10 $\mu \mathrm{M}$ NDI-DM, (S) with $10 \mu \mathrm{M}$ cNDI1, (T) with $10 \mu \mathrm{M}$ cNDI2, (U) with $10 \mu \mathrm{M}$ TMPyP4, (V) with $10 \mu \mathrm{M}$ NMM, (W) with $50 \mu \mathrm{M}$ fisetin, and $(\mathrm{X})$ with $10 \mu \mathrm{M}$ BMVC-8C30. The reactions were carried out with $1 \mu \mathrm{M} \mathrm{KF}$ and $250 \mu \mathrm{M}$ dNTPs in the buffer containing $10 \mathrm{mM}$ Tris- $\mathrm{HCl}(\mathrm{pH} 7.5), 8 \mathrm{mM} \mathrm{MgCl}_{2}, 1$ or $100 \mathrm{mM} \mathrm{KCl}$, and 0 or $20 \mathrm{wt} \% \mathrm{PEG} 200$ at $37^{\circ} \mathrm{C}$. The blue lines are fits using Dynafit software. All plots (red circle) show the results of triplicate reactions in each condition. Each inset indicates the fitting results of the ratio of $\left[P_{0}\right]$ (black), $\left[P_{\mathrm{S}}\right]$ (purple), and $\left[P_{\mathrm{F}}\right]$ (blue) in a single time course of the PAGE data (red circle), from which the $k_{\mathrm{s}}$ and $k_{\mathrm{f}}$ values were derived. 
(A)

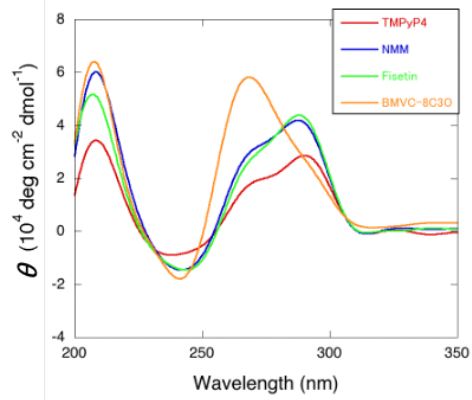

(C)

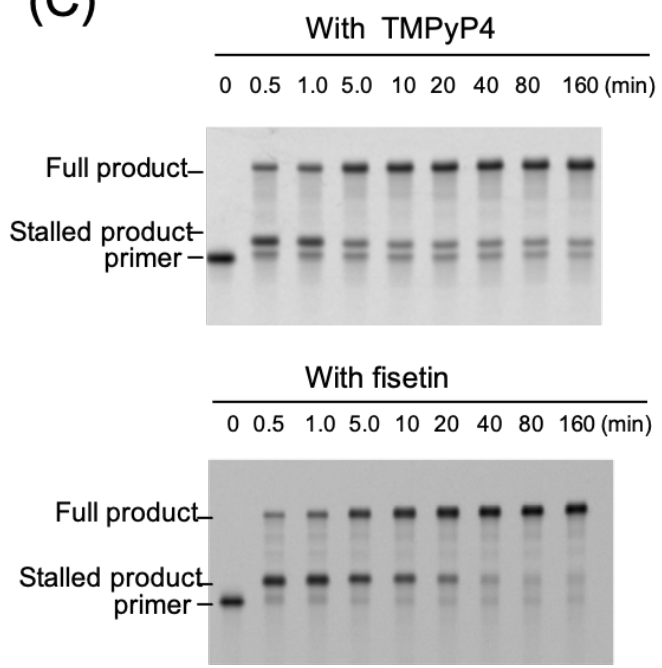

(B)

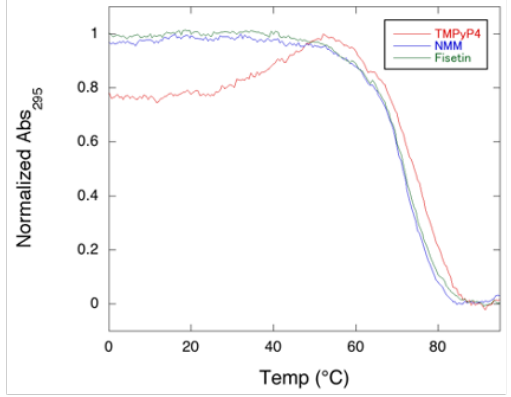

With NMM

$\begin{array}{lllllllll}0 & 0.5 & 1.0 & 5.0 & 10 & 20 & 40 & 80 & 160(\mathrm{~min})\end{array}$

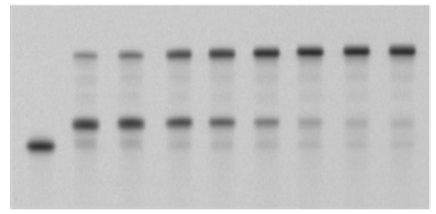

\begin{tabular}{lllllllll}
\multicolumn{6}{c}{ With BMVC-8C30 } \\
\hline 0 & 0.5 & 1.0 & 5.0 & 10 & 20 & 40 & 80 & $160(\min )$
\end{tabular}

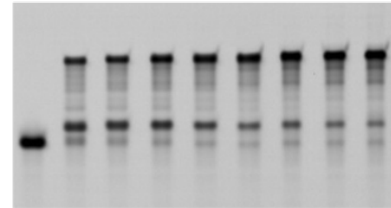

Figure S3. (A) CD spectra of $5 \mu \mathrm{M} \mathrm{hTel}$ with $10 \mu \mathrm{M}$ TMPyP4 (red), $10 \mu \mathrm{M}$ NMM (blue), $50 \mu \mathrm{M}$ fisetin (green), and $5 \mu \mathrm{M}$ hTel24, with $10 \mu \mathrm{M}$ BMVC-8C3O (orange) in the presence of $100 \mathrm{mM} \mathrm{KCl}$ at $37^{\circ} \mathrm{C}$. (B) UV melting curves of $5 \mu \mathrm{M}$ hTel in the presence of $100 \mathrm{mM} \mathrm{KCl}$ with10 $\mu \mathrm{M}$ NMM, $10 \mu \mathrm{M}$ TMPyP4, or $50 \mu \mathrm{M}$ fisetin. (D) PAGE results for the time course of the replication of $1 \mu \mathrm{M} \mathrm{hTel-}$ or hTel24 (only for the case of BMVC-8C3O)-containing template DNA in the presence of $100 \mathrm{mM}$ $\mathrm{KCl}$ in the absence or presence of each ligand. The reaction was carried out with $1 \mu \mathrm{M}$ KF exo- and $250 \mu \mathrm{M}$ dNTPs. All experiments were performed in a buffer containing $10 \mathrm{mM}$ Tris- $\mathrm{HCl}(\mathrm{pH} 7.5)$ and $8 \mathrm{mM} \mathrm{MgCl}_{2}$ at $37^{\circ} \mathrm{C}$. 


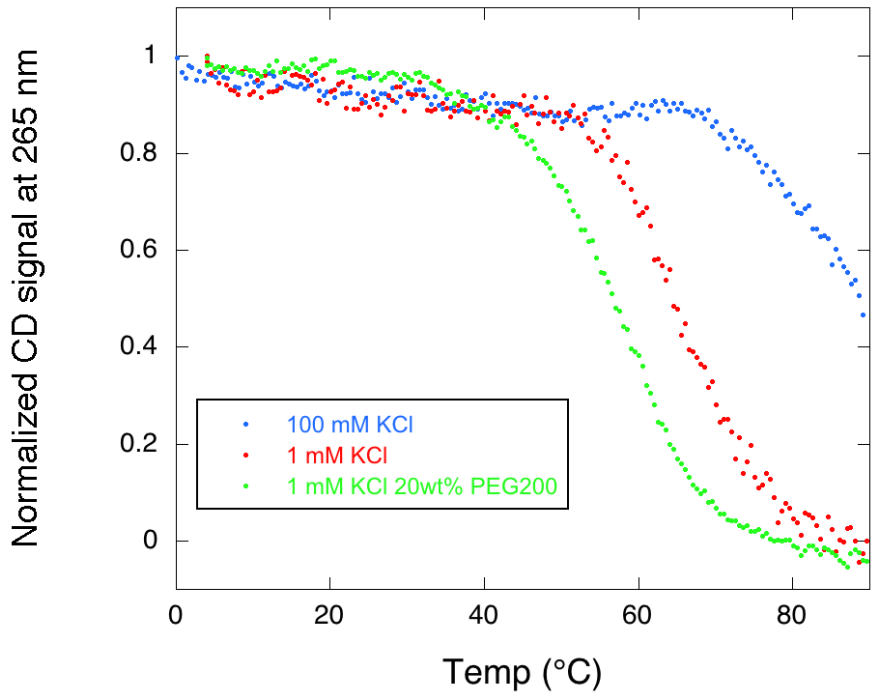

Figure S4. Normalized CD melting curves of $5 \mu \mathrm{M} \mathrm{hTel24}$ with BMVC-8C3O in the presence of (blue) $100 \mathrm{mM} \mathrm{KCl}$ without PEG200, (red) $1 \mathrm{mM} \mathrm{KCl}$ without PEG200 and (green) $1 \mathrm{mM} \mathrm{KCl}$ with 20wt\% PEG200. All experiments were measured at $265 \mathrm{~nm}$ and performed in a buffer containing $10 \mathrm{mM}$ Tris- $\mathrm{HCl}(\mathrm{pH} 7.5)$ and $8 \mathrm{mM} \mathrm{MgCl}$. 
(A)

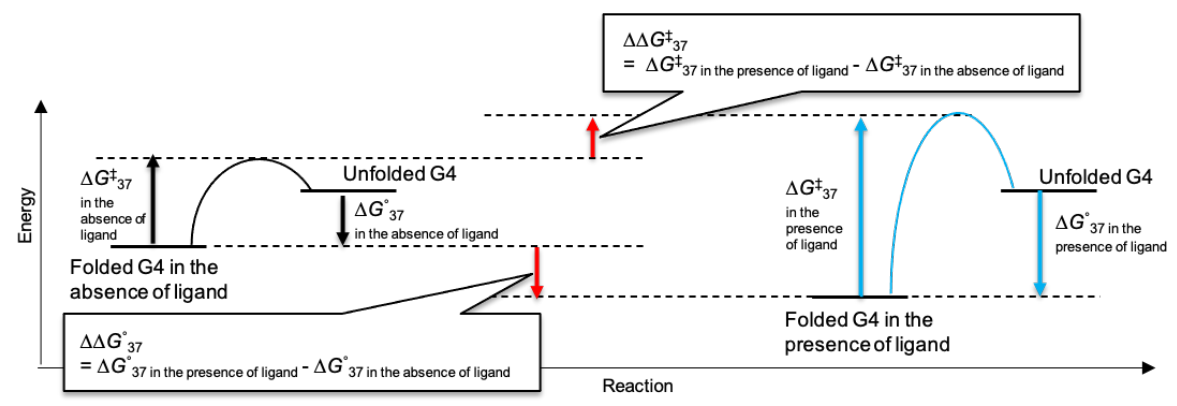

(B)

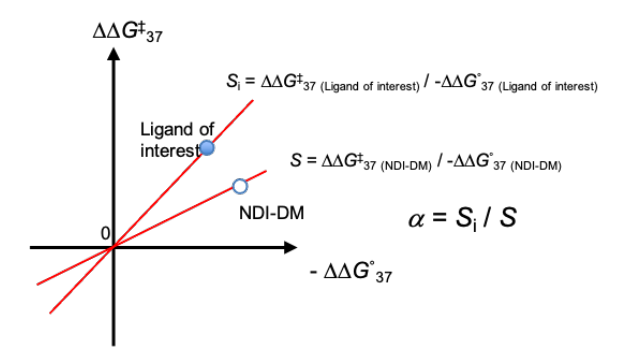

$\alpha=1$

$\Delta \Delta G_{37 \text { (Ligand of interest) }}^{\ddagger} /-\Delta \Delta G_{37 \text { (Ligand of interest) }}^{\circ}=\Delta \Delta G^{\ddagger}{ }_{37 \text { (NDI-DM) }} /-\Delta \Delta G_{37 \text { (NDI-DM) }}^{\circ}$
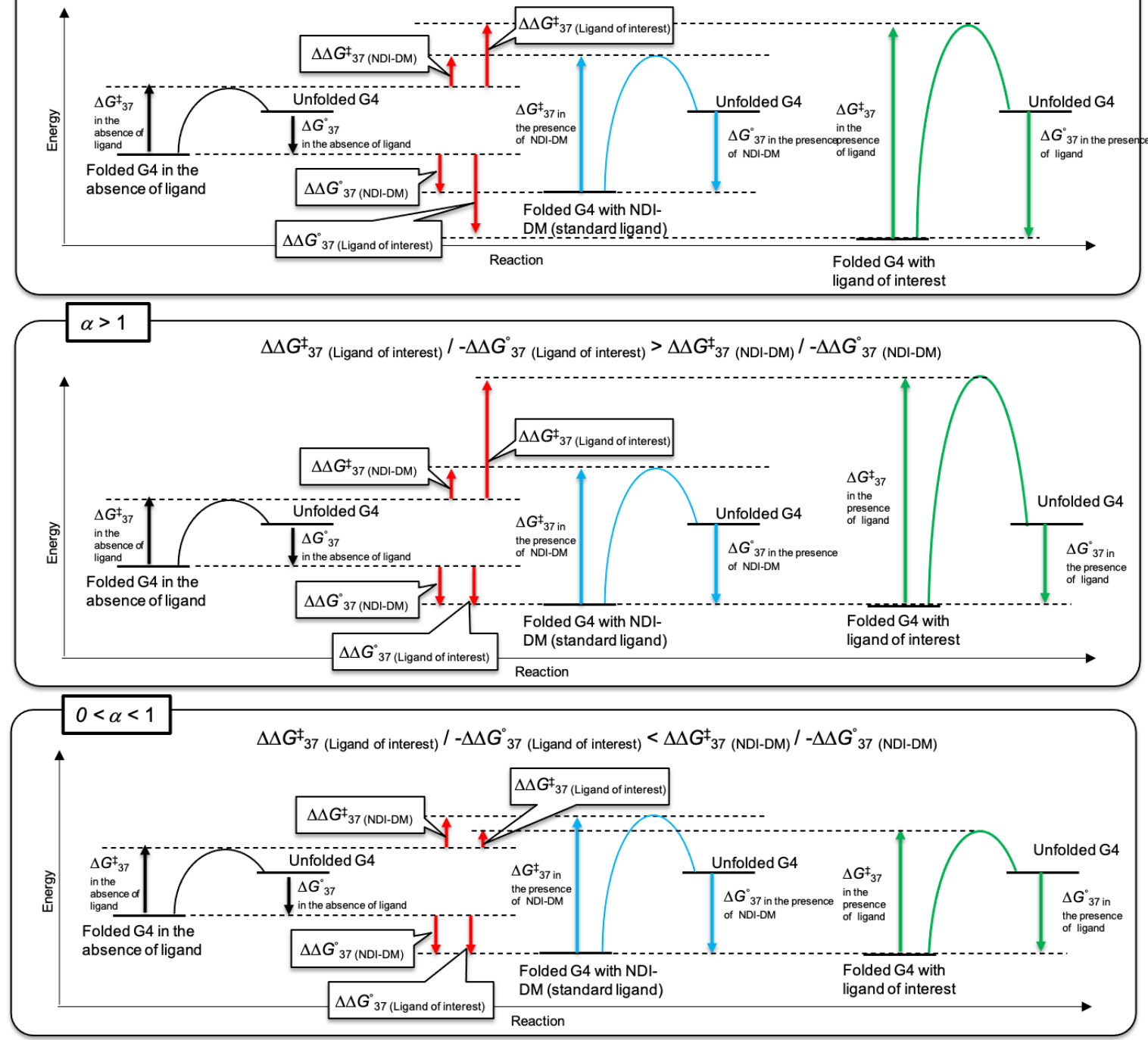

\section{Continued}


(C)
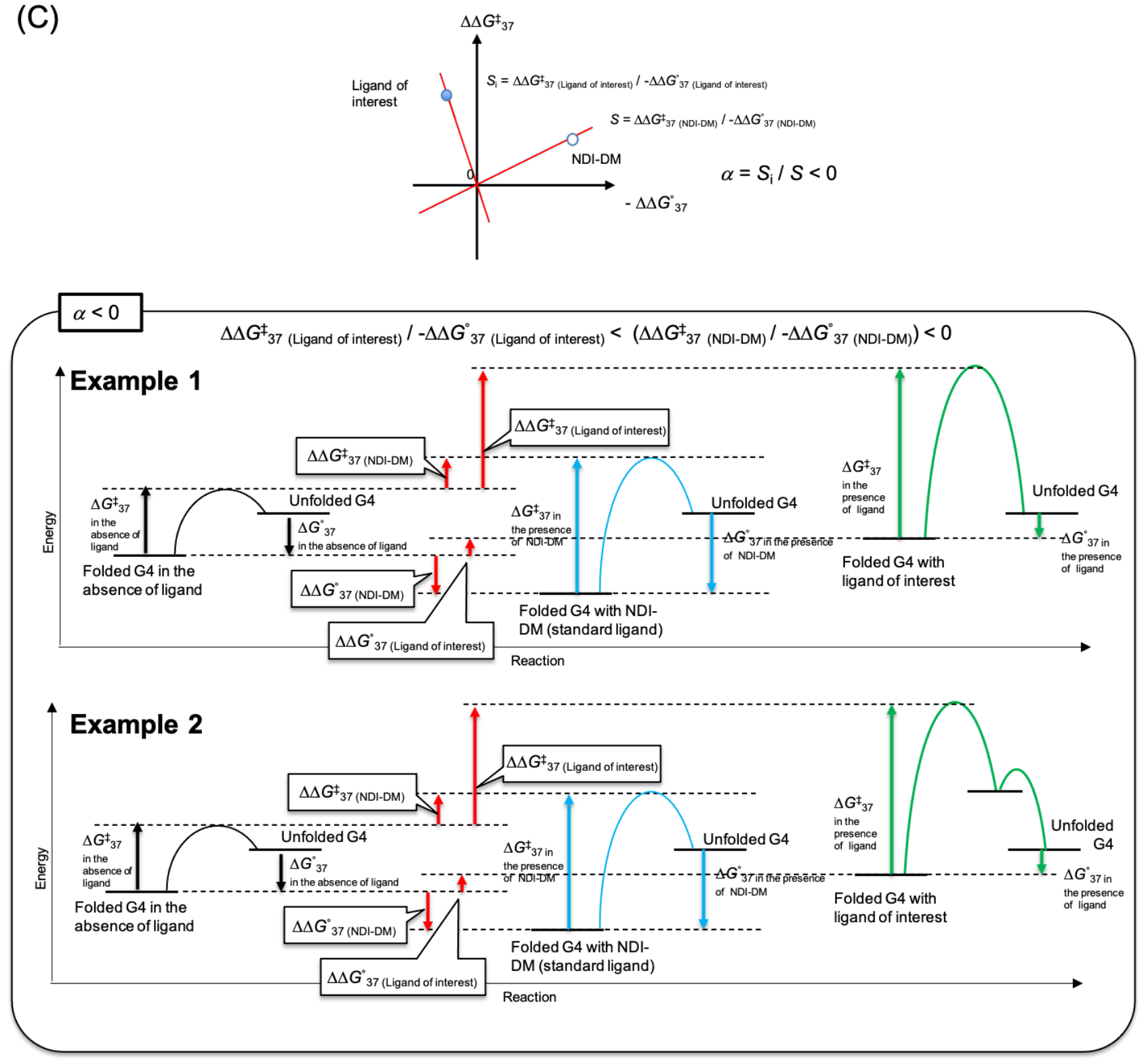

Figure S5. Schematic illustration of the QSTR analysis. (A) Energy diagram of the unwinding process of G4 by polymerase in the absence and presence of the ligand. $(\mathrm{B}, \mathrm{C})$ Graphical explanation of the definition of $\alpha$ and the interpretation of different magnitudes of $\alpha$. The cases of $\alpha>1$ and $0<\alpha<1$ are the examples when the $\Delta G^{\circ}{ }_{37}$ of the G4 with ligand of interest is as same as that with NDI-DM. 

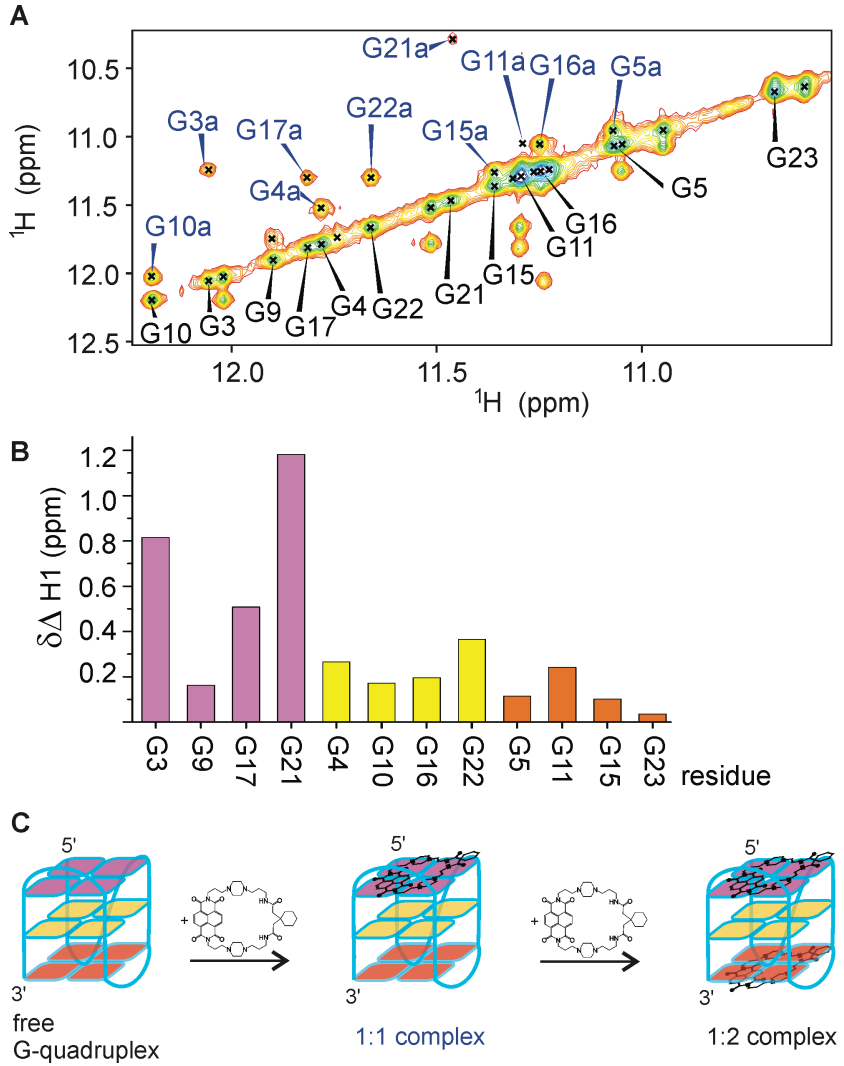
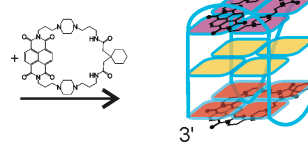

$1: 2$ complex

Figure S6. Binding of cNDI2 to hTel G-quadruplex. (A) The imino-imino region of NOESY spectrum ( $\left.\mathrm{Tm}_{\mathrm{m}} 80 \mathrm{~ms}\right)$ of hTel at a 1:0.75 hTel/ligand ratio. Diagonal cross-peaks corresponding to free G-quadruplex are labelled in black. Cross-peaks arising from chemical exchange between free G-quadruplex and in 1:1 complex are marked in blue. (B) Chemical shift changes of $\mathrm{H} 1$ protons due to the complex formation between hTel and cNDI2. The chemical shift differences (in ppm) are obtained by taking the difference between the bound (1:1 complex) and the free hTel G-quadruplex. (C) Schematic presentation of binding of cNDI2 to hTel G-quadruplex. 


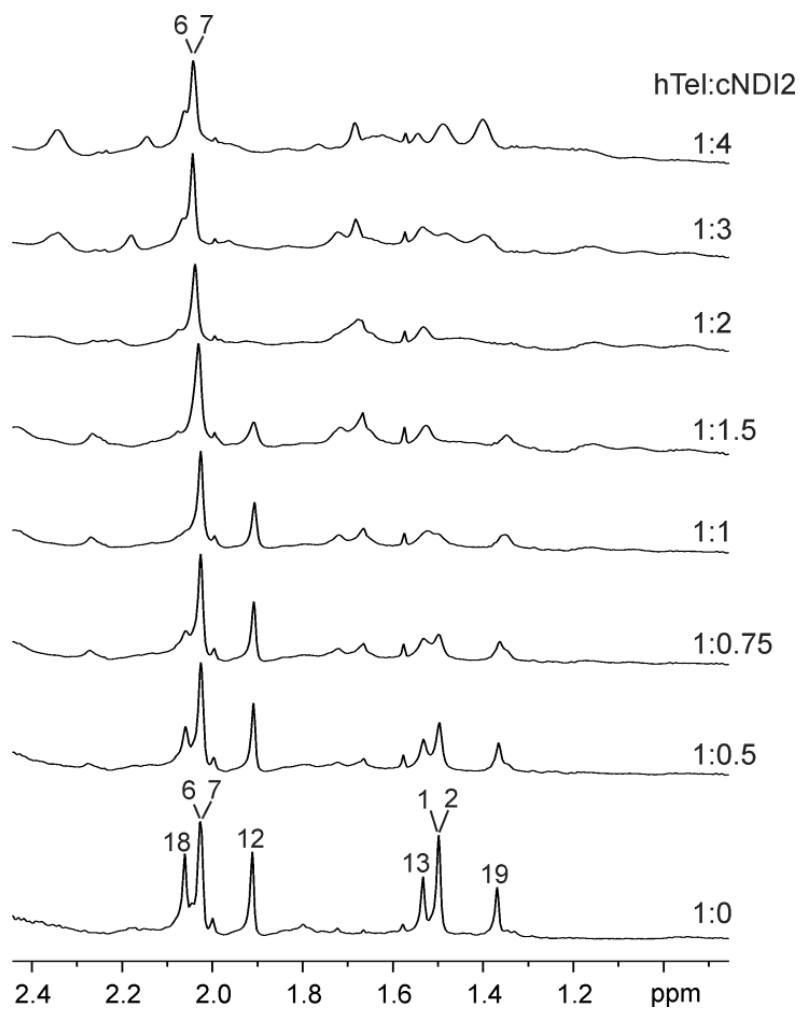

Figure S7. The enlarged ${ }^{1} \mathrm{H}$ NMR spectra of hTel as cNDI2 is titrated into solution shown in Figure $5 \mathrm{C}$. The molar ratio between $\mathrm{G} 4$ and cNDI2 is indicated on the left side of spectra. Assignments of $\mathrm{H} 1$ protons of free G4 are shown above the corresponding spectra. The NMR spectra were recorded at $0.2 \mathrm{mM}$ DNA per strand, $70 \mathrm{mM} \mathrm{KCl}, \mathrm{pH} 7.0$ and $25^{\circ} \mathrm{C}$ on a $600 \mathrm{MHz}$ NMR spectrometer. 
(A)

(C)
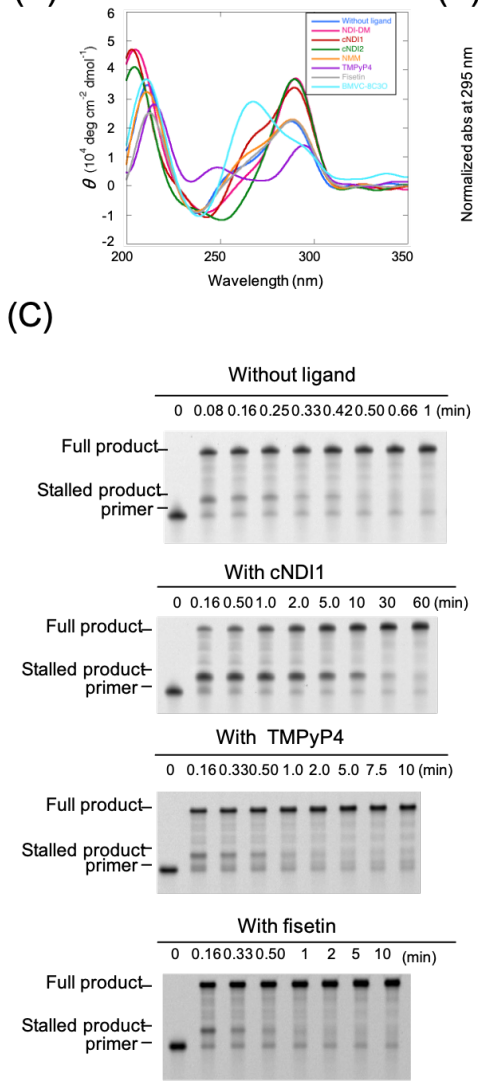

(B)
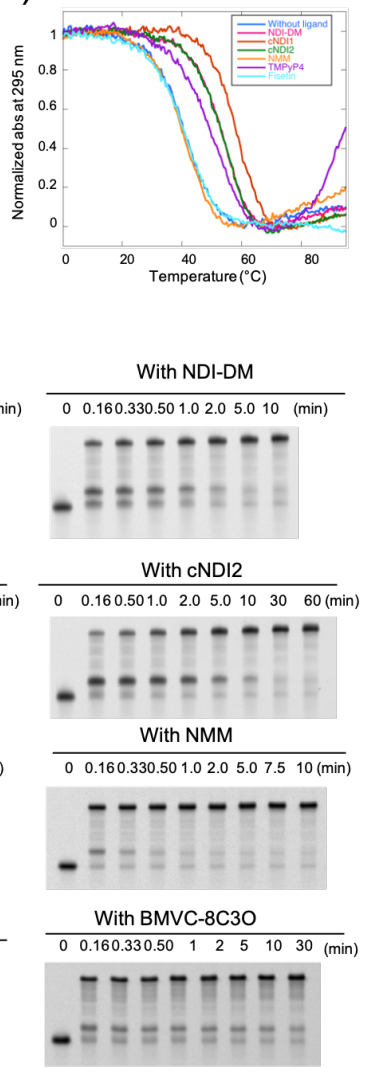

(D)

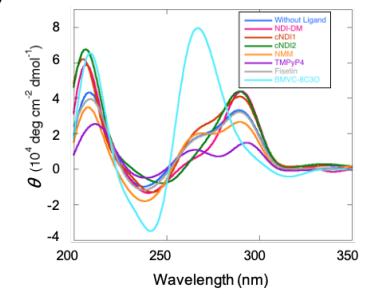

$(\mathrm{F})$

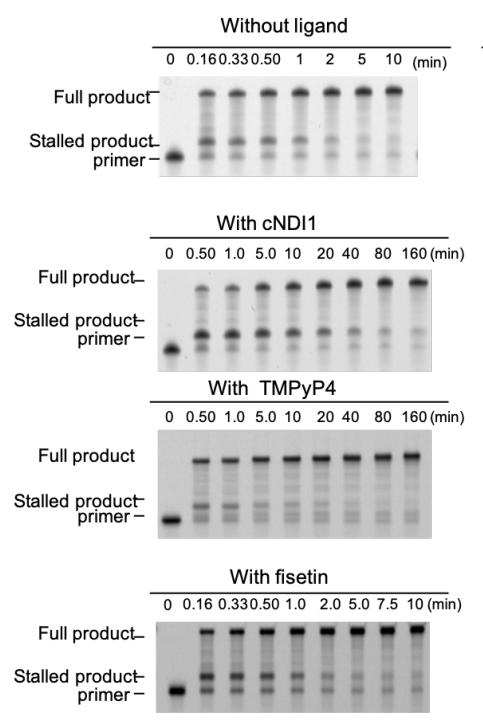

(E)
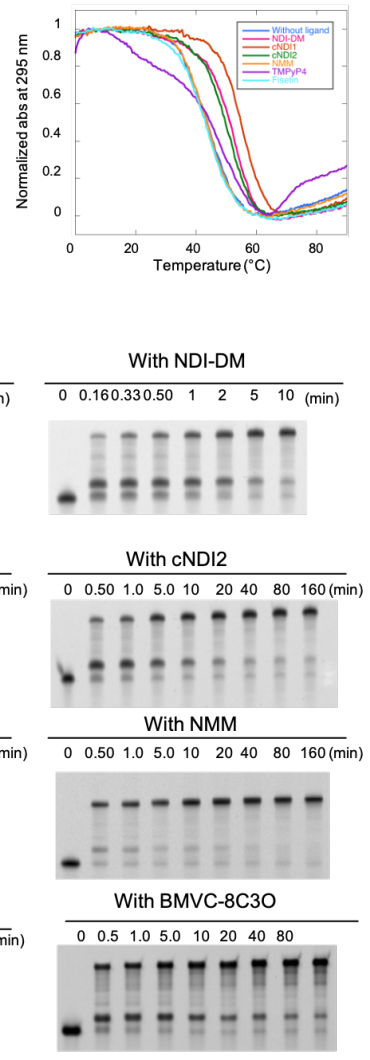

Figure S8. (A) CD spectra of $5 \mu \mathrm{M} \mathrm{hTel}$ in the presence of $1 \mathrm{mM} \mathrm{KCl}$ without ligand (blue) and with $10 \mu \mathrm{M}$ NDI-DM (pink), cNDI1 (brown), cNDI2 (green), NMM (orange), TMPyP4 (purple), or $50 \mu \mathrm{M}$ fisetin (gray), and $5 \mu \mathrm{M}$ hTel24, with $10 \mu \mathrm{M}$ BMVC-8C3O (light blue), at $37^{\circ} \mathrm{C}$. (B) UV melting curves of $5 \mu \mathrm{M} \mathrm{hTel}$ in the presence of $1 \mathrm{mM} \mathrm{KCl}$ without ligand (blue) and with $10 \mu \mathrm{M}$ NDI-DM (pink), cNDI1 (brown), cNDI2 (green), NMM (orange), TMPyP4 (purple), or $50 \mu \mathrm{M}$ fisetin (light blue). (C) PAGE results for the time course of the replication of $1 \mu \mathrm{M} \mathrm{hTel-}$ or hTel24 (only for the case of BMVC-8C3O)-containing template DNA in the presence of $1 \mathrm{mM} \mathrm{KCl}$ in the absence or presence of each ligand. The reaction was carried out with 1 $\mu \mathrm{M}$ KF exo- and $250 \mu \mathrm{M}$ dNTPs. (D) CD spectra of $5 \mu \mathrm{M}$ hTel in the presence of $20 \mathrm{wt} \%$ PEG200 without ligand (blue) and with $10 \mu \mathrm{M}$ NDI-DM (pink), cNDI1 (brown), cNDI2 (green), NMM (orange), TMPyP4 (purple), or $50 \mu \mathrm{M}$ fisetin (gray), and 5 $\mu \mathrm{M}$ hTel24 with $10 \mu \mathrm{M}$ BMVC-8C30 (light blue), at $37^{\circ} \mathrm{C}$. (E) UV melting curves of $5 \mu \mathrm{M}$ hTel in the presence of 20 wt $\%$ PEG200 without ligand (blue) and with $10 \mu \mathrm{M}$ NDI-DM (pink), cNDI1 (brown), cNDI2 (green), NMM (orange), TMPyP4 (purple), or $50 \mu \mathrm{M}$ fisetin (light blue). (F) PAGE results for time courses of the replication of $1 \mu \mathrm{M}$ hTel- or hTel24 (only for the case of BMVC-8C3O)-containing template DNA in the presence of $20 \mathrm{wt} \%$ PEG200 in the absence or presence of each ligand. The reaction was carried out with $1 \mu \mathrm{M} \mathrm{KF}$ exo- and $250 \mu \mathrm{M}$ dNTPs. All experiments were performed in a buffer containing $10 \mathrm{mM}$ Tris- $\mathrm{HCl}(\mathrm{pH} 7.5)$ and $8 \mathrm{mM} \mathrm{MgCl}_{2}$ at $37^{\circ} \mathrm{C}$. 
(A)

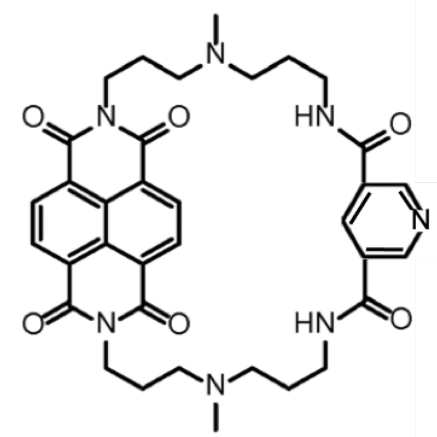

(C)

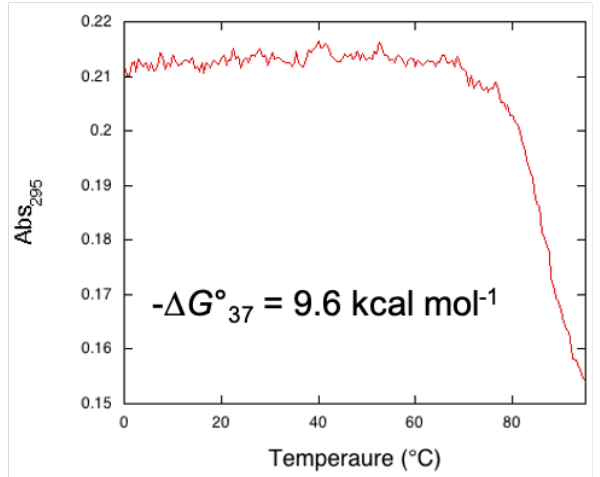

(E)

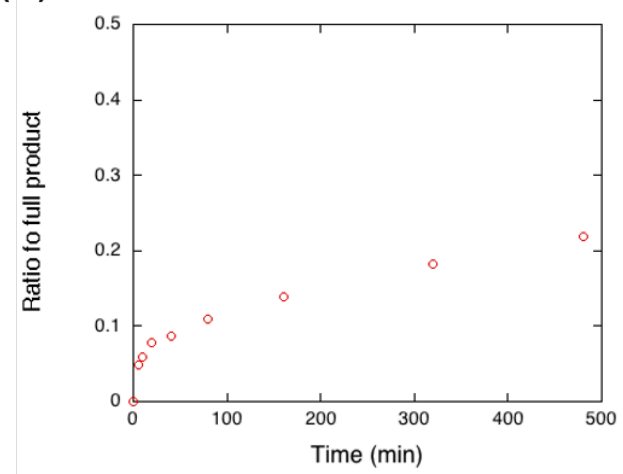

(B)

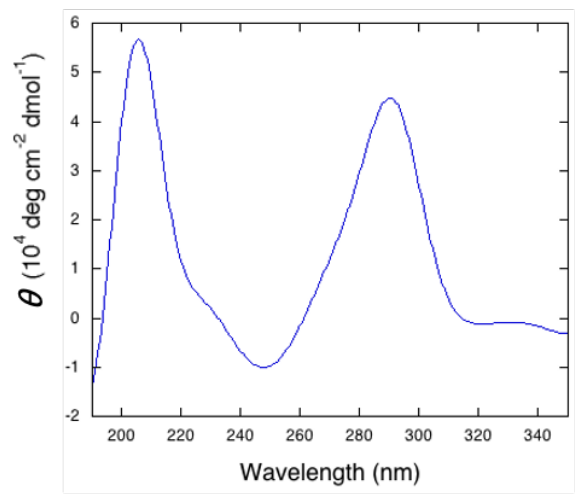

(D)

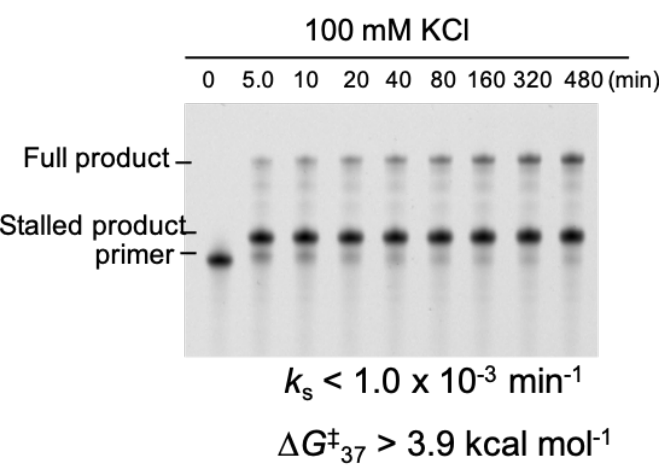

Figure S9. (A) The chemical structure of cNDI1-py. (B) CD spectra of hTel with cNDI1-py in the $100 \mathrm{mM} \mathrm{KCl} \mathrm{condition.} \mathrm{(C)}$ UV melting profile of hTel with cNDI1-py in the $100 \mathrm{mM} \mathrm{KCl}$ condition. (D) PAGE images of time course of the replication of $1 \mu \mathrm{M} \mathrm{hTel}$-containing template DNA in the presence of $100 \mathrm{mM} \mathrm{KCl}$ and in the presence of $10 \mu \mathrm{M}$ cNDI1-py. The reactions were carried out with $1 \mu \mathrm{M}$ hTel template, $1 \mu \mathrm{M} \mathrm{KF}$ and $250 \mu \mathrm{M}$ dNTPs in the buffer containing $10 \mathrm{mM}$ Tris- $\mathrm{HCl}(\mathrm{pH} 7.5), 8$ $\mathrm{mM} \mathrm{MgCl}_{2}$, and $100 \mathrm{mM} \mathrm{KCl}$ at $37^{\circ} \mathrm{C}$. (E) Kinetic analyses of full-length product formation in reactions shown in (D). 
(A)

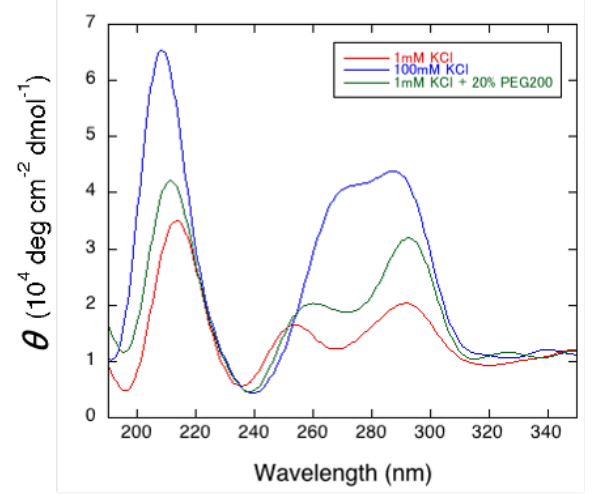

(C)

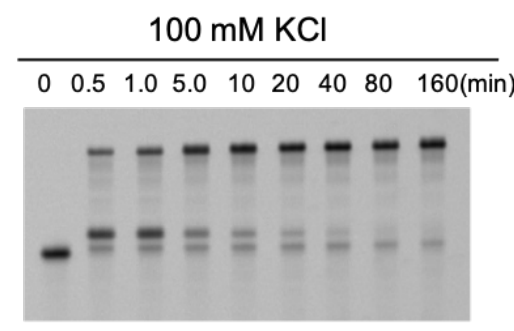

(B)

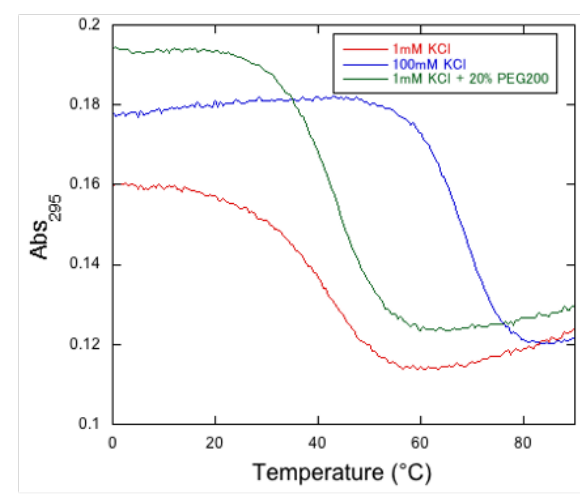

(D)

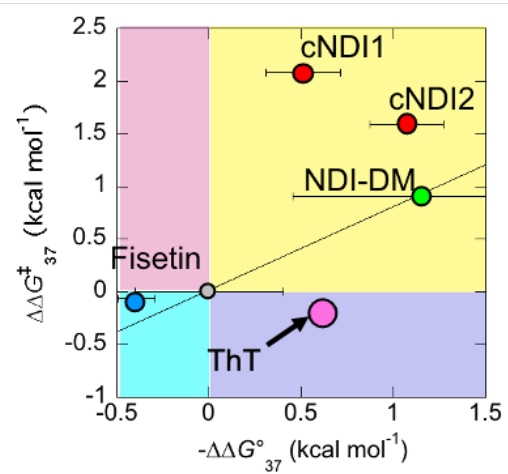

Figure S10. (A) CD spectra of $5 \mu \mathrm{M} \mathrm{hTel}$ with $10 \mu \mathrm{M} \mathrm{ThT}$ in the presence of $100 \mathrm{mM} \mathrm{KCl}, 1 \mathrm{mM} \mathrm{KCl}$, and $1 \mathrm{mM} \mathrm{KCl}$ with 20wt\% PEG200. (B) UV melting curves of $5 \mu \mathrm{M} \mathrm{hTel}$ with $10 \mu \mathrm{M} \mathrm{ThT}$ in the presence of $100 \mathrm{mM} \mathrm{KCl}, 1 \mathrm{mM} \mathrm{KCl}$, and $1 \mathrm{mM}$ $\mathrm{KCl}$ with 20wt\% PEG200. (C) PAGE results for the time course of the replication of $1 \mu \mathrm{M} \mathrm{hTel-containing} \mathrm{template} \mathrm{DNA} \mathrm{in}$ the presence of with $10 \mu \mathrm{M} \mathrm{ThT}$ in the presence of $100 \mathrm{mM} \mathrm{KCl}$. (D) QSTR assay by ThT in the presence of $100 \mathrm{mM} \mathrm{KCl}$. 
(A)

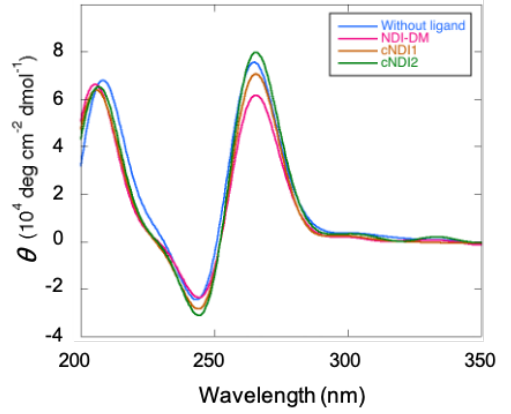

(C)
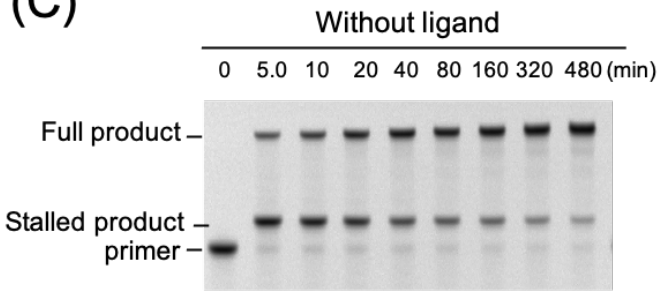

With cNDI1

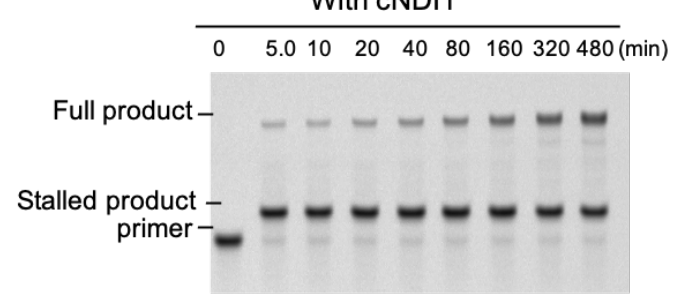

(D)

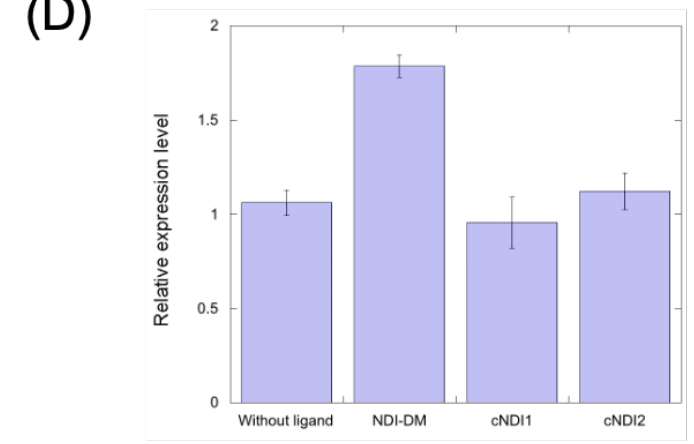

(B)
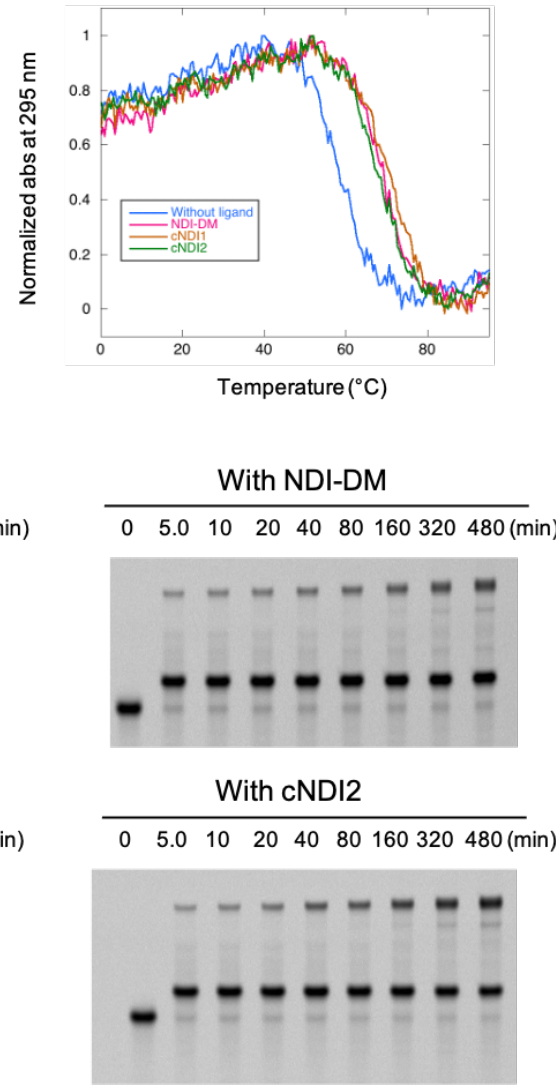

Figure S11. (A) CD spectra of $5 \mu \mathrm{M} \mathrm{C-Myc} \mathrm{in} \mathrm{the} \mathrm{presence} \mathrm{of} 1 \mathrm{mM} \mathrm{KCl}$ without ligand (blue) and with $10 \mu \mathrm{M} \mathrm{NDI-DM} \mathrm{(pink),}$ cNDI1 (brown), and cNDI2 (green) at $37^{\circ} \mathrm{C}$. (B) UV melting curves of $5 \mu \mathrm{M} \mathrm{c}$-Myc in the presence of $1 \mathrm{mM} \mathrm{KCl}$ without ligand (blue) and with $10 \mu \mathrm{M}$ NDI-DM (pink), cNDI1 (brown), and cNDI2 (green) at $37{ }^{\circ} \mathrm{C}$. (C) PAGE results for the time course of the replication of $1 \mu \mathrm{M} \mathrm{c}-\mathrm{Myc}$-containing template DNA in the presence of $1 \mathrm{mM} \mathrm{KCl}$ in the absence or presence of each ligand. The reaction was carried out using $1 \mu \mathrm{M}$ KF exo- and $250 \mu \mathrm{M}$ dNTPs. All experiments were performed using a buffer containing $10 \mathrm{mM}$ Tris- $\mathrm{HCl}\left(\mathrm{pH} \mathrm{7.5)}\right.$ and $8 \mathrm{mM} \mathrm{MgCl}_{2}$ at $37^{\circ} \mathrm{C}$. (D) The relative expression level of endogenous ubiquitin mRNA against $ß$-actin mRNA 24 hour after the addition of $0.5 \mathrm{uM}$ each ligand measured by qRT-PCR. 